\title{
Antioxidant and Renoprotective Effects of Mushroom Extract: Implication in Prevention of Nephrolithiasis
}

\author{
Ariel Schulman ${ }^{a}$, Matthew Chaimowitz ${ }^{\mathrm{a}}$, Muhammad Choudhury ${ }^{\mathrm{a}}$, Majid Eshghia, \\ Sensuke Konno ${ }^{\mathrm{a}, \mathrm{b}}$
}

\begin{abstract}
Background: The pathogenesis of nephrolithiasis (kidney stone) remains elusive, while several therapeutic options are available but not effective as we expected. Accumulating data yet suggest that oxidative stress (generation of oxygen free radicals) may play a primary role in its occurrence. Particularly, calcium oxalate $(\mathrm{CaOx})$ is a key element in the most common form $(>75 \%)$ of kidney stones, and its crystal form known as $\mathrm{CaOx}$ monohydrate (COM) has been shown to exert oxidative stress, facilitating $\mathrm{CaOx}$ stone formation. Hence, diminishing oxidative stress with certain antioxidants could be a potential strategic approach. We are interested in a bioactive extract of Poria mushroom, PE, which has been shown to have antioxidant and renoprotective activities. Accordingly, we investigated if PE might have antioxidant activity that would have implication in prevention of kidney stone formation.
\end{abstract}

Methods: Renal epithelial LLC-PK 1 cells were employed and exposed to COM or hydrogen peroxide $\left(\mathrm{H}_{2} \mathrm{O}_{2}\right)$ as a positive control capable of exerting oxidative stress. Possible antioxidant and protective effects of PE against oxidative stress (exerted by COM or $\mathrm{H}_{2} \mathrm{O}_{2}$ ) were assessed by cell viability test and lipid peroxidation (LPO) assay. To explore its protective mechanism, two glycolytic parameters, hexokinase (HK) activity and ATP synthesis, were examined and cell cycle analysis was also performed.

Results: Both $\mathrm{H}_{2} \mathrm{O}_{2}$ and COM led to a significant $(\mathrm{P}<0.05)$ reduction in cell viability, accompanied by severe oxidative stress assessed by LPO assay. Such oxidative stress also caused the significant decline in HK activity and cellular ATP level, indicating the inhibition of glycolysis. Cell cycle analysis further indicated that oxidative stress interfered with cell cycle, inducing a $\mathrm{G}_{1}$ cell cycle arrest that presumably results in the cessation of cell proliferation. However, PE was capable of significantly preventing or diminishing all these cellular effects mediated through oxidative stress (exerted by $\mathrm{H}_{2} \mathrm{O}_{2}$ and $\mathrm{COM}$ ).

Conclusions: The present study shows that the mushroom extract $\mathrm{PE}$ appears to have antioxidant and renoprotective effects against

Manuscript accepted for publication October 05, 2016

aDepartment of Urology, New York Medical College, Valhalla, NY, USA ${ }^{b}$ Corresponding Author: Sensuke Konno, Department of Urology, New York Medical College, BSB Room A03, Valhalla, NY 10595, USA.

Email: sensuke_konno@nymc.edu

doi: http://dx.doi.org/10.14740/jocmr2781w oxidative stress exerted by COM in renal cells. Therefore, PE with antioxidant activity is considered a promising natural agent that may have clinical implications in prevention of nephrolithiasis primarily induced by oxidative stress.

Keywords: Mushroom extract; Antioxidant; Oxidative stress; Nephrolithiasis

\section{Introduction}

Oxidative stress or generation of oxygen free radicals during aerobic metabolic process [1] is one of major causes for cellular damage/dysfunction. Accumulating data suggest that such oxidative stress could be a primary cause of various renal cell injury/damage as well $[1,2]$. Those include acute renal injuries by ischemia/reperfusion, nephrotoxic agents, or even by extracorporeal shock wave lithotripsy that is one of therapeutic procedures for removal of kidney stones $[3,4]$. Thus, many renal diseases/disorders due to real cell injury are somehow linked to the certain degrees of oxidative stress.

In fact, renal cell injury is also considered a major risk factor for crystal deposition in the kidneys (nephrolithiasis) [5, 6]. In particular, calcium oxalate $(\mathrm{CaOx})$ is a key element in the most common form ( $>75 \%)$ of kidney stones [7] but a binding of $\mathrm{CaOx}$ crystals to the renal tubular epithelium is believed to be required for the ultimate stone development [8]. In addition, renal cell injury appears to be pre-requisite for such $\mathrm{CaOx}$ binding to the urothelium $[9,10]$. In other words, no $(\mathrm{CaOx})$ stone development is possible unless $\mathrm{CaOx}$ crystals bind to the renal tubular cells that were already injured or damaged. Actually, crystallization of $\mathrm{CaOx}$ forms or becomes " $\mathrm{CaOx}$ monohydrate (COM)" $[5,10]$, which has been shown to facilitate a stone formation through oxidative stress.

If oxidative stress were indeed the critical factor for such kidney stone formation, it is plausible that antioxidants might be able to prevent or reduce the incidence of nephrolithiasis. In fact, antioxidant enzymes such as catalase and superoxide dismutase and chemical (non-enzymatic) antioxidant, vitamin $\mathrm{E}$, have been shown to effectively reduce oxidative stress, resulting in decreased renal cell injury and crystal deposition in the kidneys [11]. Our previous study also demonstrated that a potent antioxidant, N-acetylcysteine (NAC), was capable of significantly $(>70 \%)$ preventing and reducing chemically induced $\mathrm{CaOx}$ crystal formation in rats [12]. 
Besides NAC, we were also interested in studying a natural agent that was capable of preventing kidney stone formation and came across a bioactive mushroom extract called "PE" isolated from Poria mushroom [13]. This mushroom is not a new mushroom but is one of well-established medicinal mushrooms, which has been used in traditional Chinese medicine (TCM) for 2,000 years. The major chemical constituents of PE such as triterpenes, polysaccharides, and steroids have been also identified $[13,14]$. A number of studies revealed that $\mathrm{PE}$ had renoprotective, antitumor, immunomodulatory, antibacterial, antioxidant, anti-hyperglycemic, anti-inflammatory, diuretic effects and so forth [15-21]. We are particularly interested in its renoprotective and antioxidant activities, which may help reduce the incidence of kidney stones induced by oxidative stress.

Accordingly, we investigated if PE with possible antioxidant activity would protect renal cells from oxidative stress exerted by COM. Additionally, we also explored the protective mechanism of PE against such oxidative stress. More details are described and the significant findings are also discussed herein.

\section{Materials and Methods}

\section{Cell culture}

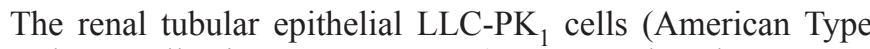
Culture Collection, Manassas, VA) were employed as our experimental model in vitro. They were maintained in RPMI1640 medium supplemented with $10 \%$ fetal bovine serum, penicillin (100 units $/ \mathrm{mL})$, and streptomycin $(100 \mu \mathrm{g} / \mathrm{mL})$. Cells were incubated at $37{ }^{\circ} \mathrm{C}$ in a $5 \% \mathrm{CO}_{2}$ and $95 \%$ air. Routinely, culture medium was changed every 3 - 4 days and the passage of cells was performed weekly.

\section{Experiments using COM and $\mathrm{PE}$}

Crystals of COM were purchased (Sigma-Aldrich, St. Louis, $\mathrm{MO}$ ) and suspended with phosphate-buffered saline (PBS) to obtain a uniform slurry COM solution $(20 \mathrm{mg} / \mathrm{mL})$. PE (Poria mushroom extract) was a gift from the manufacturer (Mushroom Wisdom, Inc., East Rutherford, $\mathrm{NJ}$ ) and dissolved in $\mathrm{H}_{2} \mathrm{O}$ to prepare a PE stock $(25 \mathrm{mg} / \mathrm{mL})$. Hydrogen peroxide $\left(\mathrm{H}_{2} \mathrm{O}_{2}\right)$ was used as a positive control for exerting oxidative stress in this study. For experiments, cells $\left(2 \times 10^{5}\right.$ cells $\left./ \mathrm{mL}\right)$ were first seeded in the six-well plates or T-75 flasks for $24 \mathrm{~h}$ and treated with the specified concentrations of $\mathrm{H}_{2} \mathrm{O}_{2}, \mathrm{COM}, \mathrm{PE}$ or their combinations for another $24 \mathrm{~h}$ (specific experimental conditions were also described in Results). Cell viability was then determined using the 3-(4,5-dimethylthiazol-2-yl)-2,5-diphenyl-tetrazolium bromide (MTT) assay described below.

\section{Cell viability test (MTT assay)}

Cell viability was determined by MTT assay following the vendor's protocol (Sigma-Aldrich, St. Louis, MO). This will indicate what $\%$ of cells is yet viable under oxidative stress (exerted by $\mathrm{H}_{2} \mathrm{O}_{2}$ or $\left.\mathrm{COM}\right)$. MTT reagent $(1 \mathrm{mg} / \mathrm{mL})$ was added to the six-well plate that was then incubated for $3 \mathrm{~h}$ at $37^{\circ} \mathrm{C}$. After MTT was discarded, dimethyl sulfoxide (DMSO) was added to the plate and the absorbance of formazan solution (purple color) was read in a microplate reader. Cell viability was expressed by the $\%$ of sample readings relative to the controls $(100 \%)$.

\section{Lipid peroxidation (LPO) assay}

The severity of oxidative stress was assessed by the LPO assay, by measuring the amount of malondialdehyde (MDA) formed in the plasma membrane, due to oxidative stress [22]. As MDA is an end product from peroxidation of polyunsaturated fatty acids, the severity of oxidative stress can be indicated as: the more MDA formed, the greater oxidative stress. The LPO colorimetric assay kit (Abcam, Cambridge, MA) was used and the procedures were described in the vendor's protocol. The amount of MDA formed (in each sample) was then expressed by $\mu \mathrm{M}$ determined from the MDA standards.

\section{Assays for hexokinase (HK) activity}

HK activity was determined by the HK Colorimetric Assay Kit (Biovision, Milpitas, CA) following the manufacturer's protocol with minor modifications. Control or agents-treated cells were lysed in HK buffer provided and supernatant (cell lysates) was obtained by centrifugation. The NADH standards and cell lysates $(20 \mu \mathrm{g}$ per sample) were prepared in the 96 -well plate and the reaction was started by the addition of reaction mix (containing substrate). Immediately the plate was placed in a microplate reader and the absorbance changes with time were monitored at $450 \mathrm{~nm}$ for $20 \mathrm{~min}$ with 5-min intervals. All readings were calculated and normalized and then HK activity was expressed by the $\%$ of sample activity relative to the controls $(100 \%)$.

\section{Determination of cellular ATP level}

The cellular ATP level was determined using the ATP Colorimetric Assay Kit (Biovision, Milpitas, CA) following the manufacturer's protocol. The reaction was started by the addition of cell lysates $(20 \mu \mathrm{L})$ to the reaction mixture in the 96-well plate. All samples including ATP standards (without cell lysates) were read at $570 \mathrm{~nm}$ on a microplate reader and ATP content in sample was calculated using ATP standards. The cellular ATP level was expressed by the $\%$ of sample readings relative to the controls $(100 \%)$.

\section{Cell cycle analysis}

A BD FACscan flow cytometer (Becton-Dickinson, Franklin Lakes, NJ), equipped with a double discrimination module, was employed for cell cycle analysis. Cells (about $1 \times 10^{6}$ cells) were resuspended in propidium iodide solution and incubated for $1 \mathrm{~h}$ at room temperature. Approximately 10,000 nuclei from 

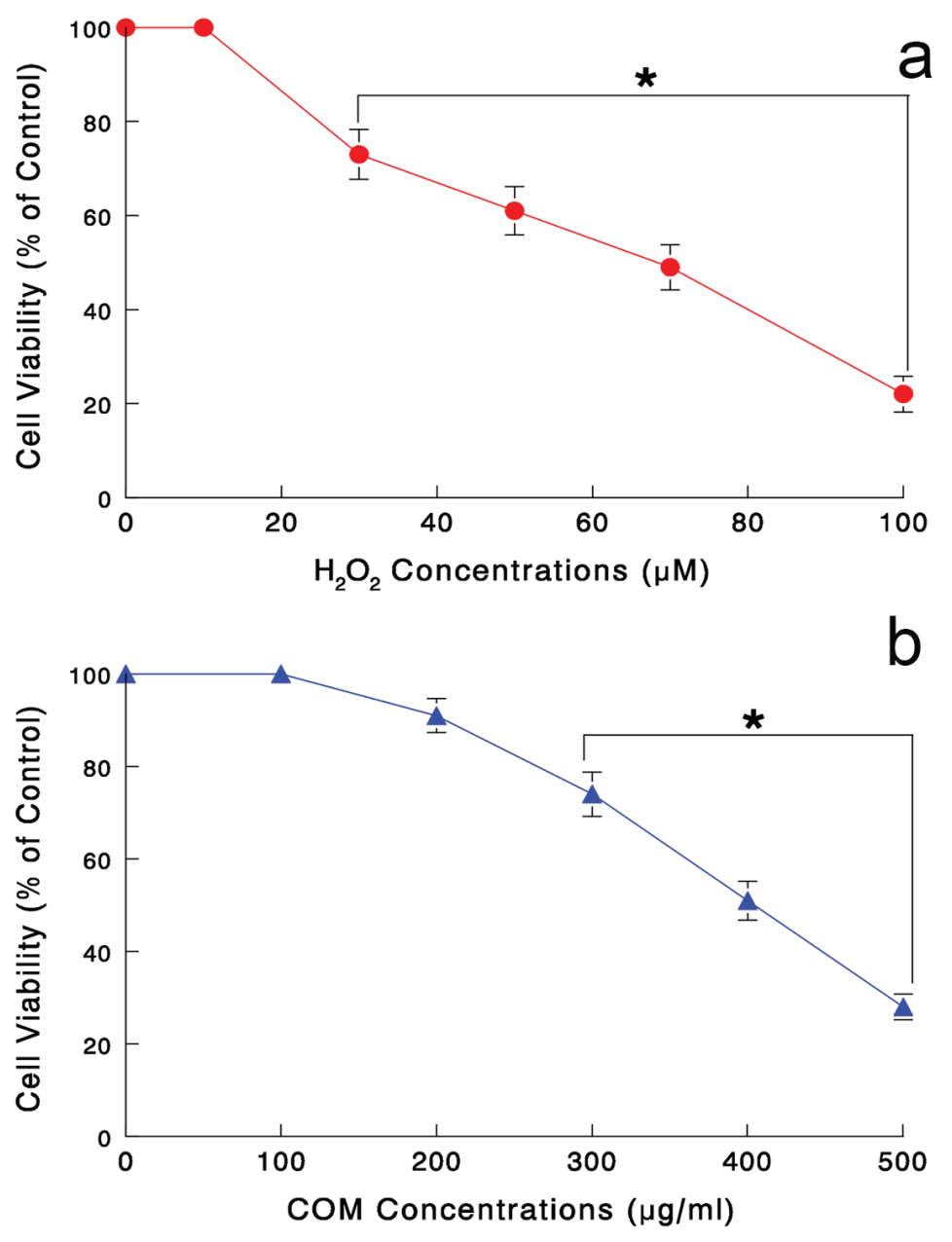

Figure 1. (a) Dose-dependent effects of $\mathrm{H}_{2} \mathrm{O}_{2}$ on LLC-PK 1 cell viability. Cells were treated with varying concentrations of $\mathrm{H}_{2} \mathrm{O}_{2}$ $(0-100 \mu \mathrm{M})$ for $24 \mathrm{~h}$ and cell viability was determined by MTT assay. All data are mean \pm SD from three independent experiments $\left({ }^{*} \mathrm{P}<0.05\right)$. (b) Dose-dependent effects of COM on cell viability. Cells exposed to varying concentrations of COM $(0-500 \mu \mathrm{g} / \mathrm{mL})$ for $6 \mathrm{~h}$ were assayed for cell viability. The data are mean $\pm \mathrm{SD}$ from three separate experiments $\left({ }^{*} \mathrm{P}<0.05\right)$.

each sample were analyzed on a flow cytometer, and CellFit software was used to quantify cell cycle compartments to estimate the $\%$ of cells distributed in the different cell cycle phases.

\section{Statistical analysis}

All data were presented as mean \pm standard deviation (SD), and statistical differences between groups were assessed with the unpaired Student's $t$-test or one-way analysis of variance (ANOVA). Values of $\mathrm{P}<0.05$ are considered to indicate statistical significance.

\section{Results}

\section{Effects of $\mathrm{H}_{2} \mathrm{O}_{2}$ or COM on LLC-PK 1 cell viability}

Cytotoxic effect of oxidative stress on renal epithelial LLC-
$\mathrm{PK}_{1}$ cells was assessed. Cells were treated with $\mathrm{H}_{2} \mathrm{O}_{2}(0-100$ $\mu \mathrm{M})$, a positive mediator of oxidative stress, for $24 \mathrm{~h}$ and cell viability was determined. Such study showed that cell viability was significantly reduced to about $70 \%, 50 \%$, and $20 \%$ with 30, 70, and $100 \mu \mathrm{M} \mathrm{H}_{2} \mathrm{O}_{2}$, respectively (Fig. 1a).

Similarly, cytotoxic effect of COM shown to exert oxidative stress [10] was also assessed. Our pilot study has indicated that 6-h exposure with varying concentrations of COM was sufficient to induce adverse effects on cell viability (data not shown). Cells were exposed to COM $(0-500 \mu \mathrm{g} / \mathrm{mL})$ for $6 \mathrm{~h}$, followed by MTT assay. COM concentrations $\geq 300 \mu \mathrm{g} / \mathrm{mL}$ led to a significant cell viability reduction, which further declined to about $30 \%$ with $500 \mu \mathrm{g} / \mathrm{mL}$ (Fig. 1b).

Thus, these results suggest that both $\mathrm{H}_{2} \mathrm{O}_{2}$ and $\mathrm{COM}$ are indeed capable of reducing cell viability, presumably through oxidative stress. The estimated $\mathrm{IC}_{50}$ values for $\mathrm{H}_{2} \mathrm{O}_{2}$ and $\mathrm{COM}$ were $70 \mu \mathrm{M}$ and $400 \mu \mathrm{g} / \mathrm{mL}$, respectively (Fig. 1a, b). Hereafter, the rest of our study was carried out following the experimental conditions with "24-h $\mathrm{H}_{2} \mathrm{O}_{2}(70 \mu \mathrm{M})$ " and "6-h COM (400 $\mu \mathrm{g} / \mathrm{mL}) "$. 


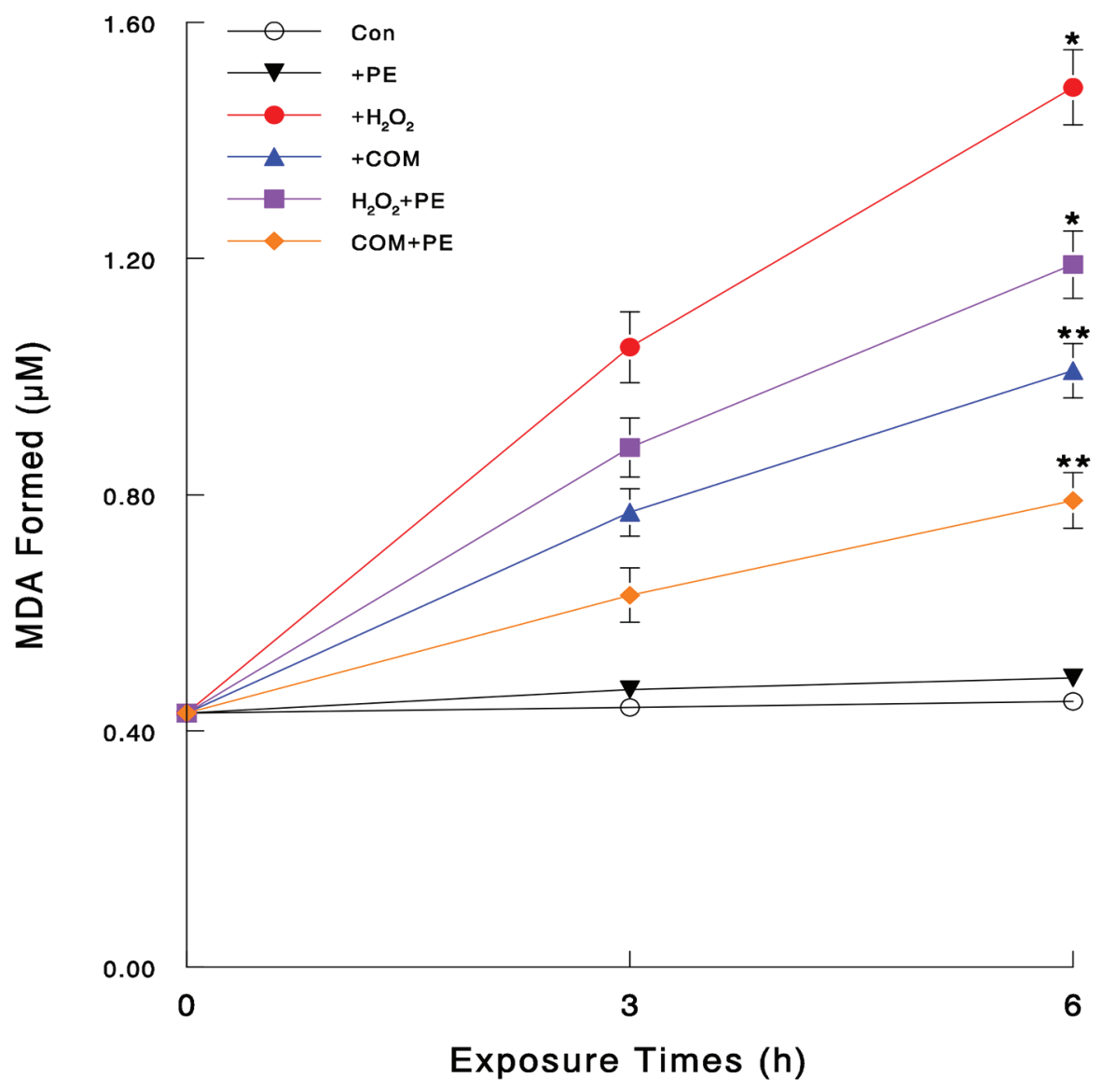

Figure 2. Severity of oxidative stress assessed by LPO assay. Cells were exposed to $\mathrm{H}_{2} \mathrm{O}_{2}(70 \mu \mathrm{M}), \mathrm{COM}(400 \mu \mathrm{g} / \mathrm{mL}), \mathrm{PE}(50$ $\mu \mathrm{g} / \mathrm{mL})$, or $\mathrm{PE}(50 \mu \mathrm{g} / \mathrm{mL})$ combined with either $\mathrm{H}_{2} \mathrm{O}_{2}(70 \mu \mathrm{M})$ or COM $(400 \mu \mathrm{g} / \mathrm{mL})$, for 3 or $6 \mathrm{~h}$. The amounts of MDA formed, assessed by LPO assay, were plotted against times. All data are mean \pm SD from three separate experiments $\left({ }^{*} P<0.03\right.$ and ${ }^{* *} P$ $<0.05$ compared with controls).

\section{Antioxidant effect of PE on oxidative stress exerted by $\mathrm{H}_{2} \mathrm{O}_{2}$ or COM}

To verify if $\mathrm{H}_{2} \mathrm{O}_{2}$ and $\mathrm{COM}$ exert oxidative stress, we directly assessed the severity of their oxidative stress by LPO assay. As damaging the plasma membrane by oxidative attack takes place at the early time, cells were exposed to $\mathrm{H}_{2} \mathrm{O}_{2}(70 \mu \mathrm{M}), \mathrm{COM}$ $(400 \mu \mathrm{g} / \mathrm{mL})$, or PE $(50 \mu \mathrm{g} / \mathrm{mL})$ alone and its combination with $\mathrm{H}_{2} \mathrm{O}_{2}$ or COM for 3 or $6 \mathrm{~h}$. LPO assay showed that no apparent changes in the amount of MDA formed were seen in control or PE-exposed cells (Fig. 2). However, $\mathrm{H}_{2} \mathrm{O}_{2}$ and $\mathrm{COM}$ led to about 3.3-fold and 2.2-fold increase (compared to controls) in the MDA amounts at 6 h, respectively (Fig. 2). Such an MDA increase was yet significantly reduced by about $20 \%$ and $22 \%$ with $\mathrm{PE}$ in $\mathrm{H}_{2} \mathrm{O}_{2}$ - and COM-exposed cells, respectively (Fig. 2). Therefore, both $\mathrm{H}_{2} \mathrm{O}_{2}$ and COM appear to exert severe oxidative stress on LLC-PK 1 cells but PE with antioxidant activity is capable of effectively blocking such oxidative assault.

\section{Renoprotective effect of PE against oxidative stress}

We next examined if PE might also protect renal cells from oxidative attack. Cells were exposed to $\mathrm{H}_{2} \mathrm{O}_{2}(70 \mu \mathrm{M}$ for 24 h), COM (400 $\mu \mathrm{g} / \mathrm{mL}$ for $6 \mathrm{~h})$, or PE $(50 \mu \mathrm{g} / \mathrm{mL}$ for $24 \mathrm{~h})$ alone and its combination with $\mathrm{H}_{2} \mathrm{O}_{2}$ or COM. MTT assay showed that both $\mathrm{H}_{2} \mathrm{O}_{2}$ and COM alone led to a significant (about 50\%) reduction in cell viability, which yet went up to about $70 \%$ and $76 \%$ with $\mathrm{PE}$ in $\mathrm{H}_{2} \mathrm{O}_{2}$ - and COM-exposed cells, respectively (Fig. 3). Thus, PE may effectively protect renal cells from oxidative stress, implying its renoprotective effect.

\section{Effects of COM on glycolysis}

Although we now know that COM could exert oxidative stress and reduce cell viability, it is yet uncertain "how" it is done. To address the relevance of this COM-induced cell viability reduction to nephrolithiasis, its cytotoxic mechanism was further explored. In particular, we examined the effects of COM on glycolysis, which is a major metabolic process for generating cellular energy (ATP) required for cellular activity, proliferation and survival $[23,24]$. Two glycolytic parameters, HK activity and ATP synthesis, were examined to assess the status of glycolysis. Cells were exposed to COM $(400 \mu \mathrm{g} / \mathrm{mL})$ or PE $(50 \mu \mathrm{g} / \mathrm{mL})$ alone or their combination $(\mathrm{COM}+\mathrm{PE})$ for $6 \mathrm{~h}$ 


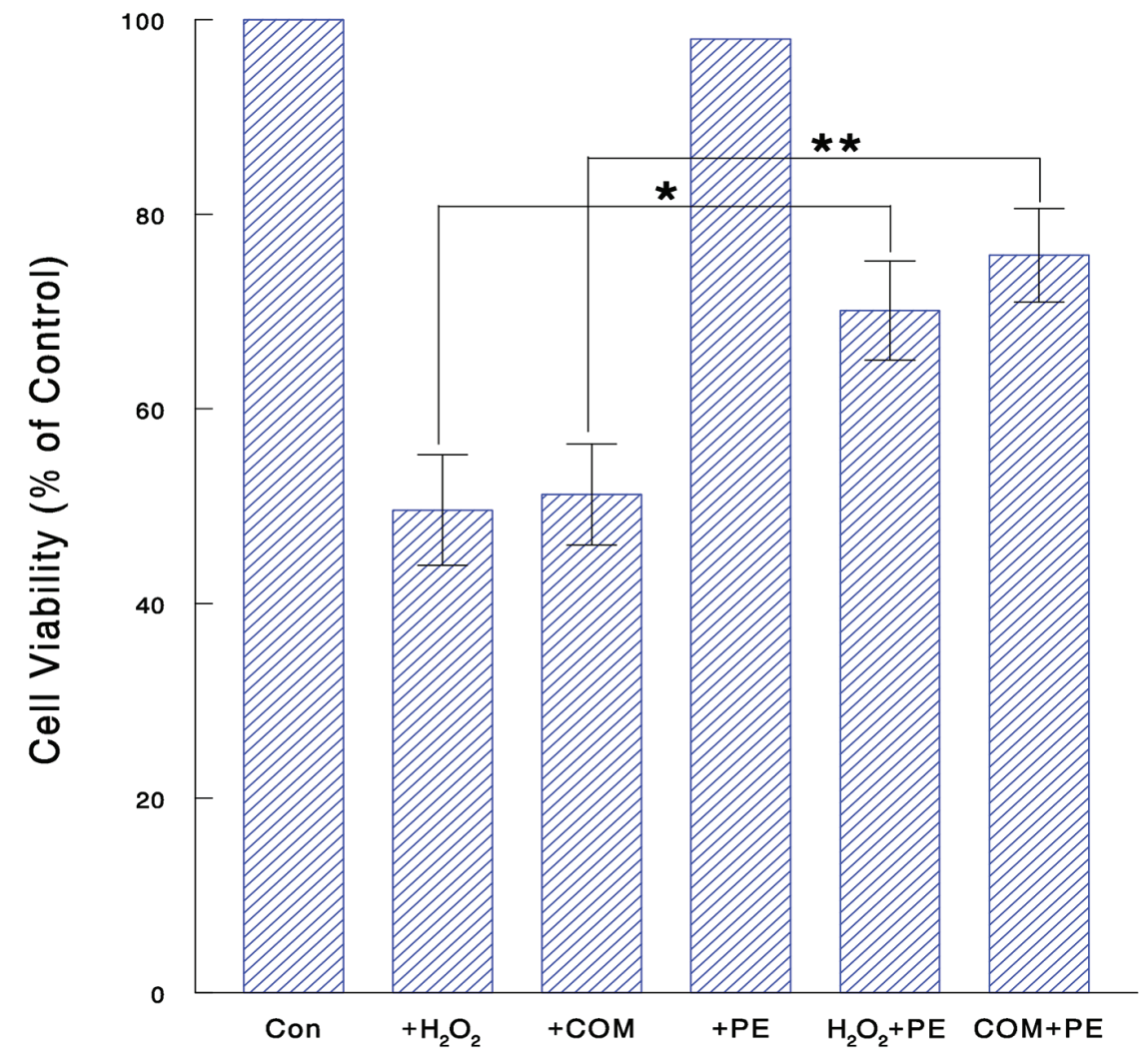

Figure 3. Renoprotective effect of PE against oxidative stress. Cells were treated with $\mathrm{H}_{2} \mathrm{O}_{2}(70 \mu \mathrm{M}$ for $24 \mathrm{~h}), \mathrm{COM}(400 \mu \mathrm{g} / \mathrm{mL}$ for $6 \mathrm{~h}$ ), $\mathrm{PE}\left(50 \mu \mathrm{g} / \mathrm{mL}\right.$ for $24 \mathrm{~h}$ ), or PE combined with $\mathrm{H}_{2} \mathrm{O}_{2}$ (for $24 \mathrm{~h}$ ) or COM (for $6 \mathrm{~h}$ ). Cell viability was determined and the data are mean \pm SD from three independent experiments $\left({ }^{*} \mathrm{P}<0.05\right.$; $\left.{ }^{* *} \mathrm{P}<0.03\right)$.

and assayed for HK activity and ATP synthesis. Compared to controls (100\%), HK activity and ATP level declined to about $43 \%$ and $38 \%$ with COM, respectively (Fig. 4). This indicates that glycolysis is critically inhibited by COM, leading to cellular ATP depletion, followed by the growth cessation. However, PE significantly increased such COM-reduced HK activity and ATP level up to about $67 \%$ and $62 \%$, respectively (Fig. 4). Therefore, PE may effectively prevent the glycolysis inhibition induced by COM, by sustaining the high levels of $\mathrm{HK}$ and cellular ATP.

\section{Effect of COM on cell cycle}

As the glycolysis inhibition has been also shown to interfere with cell cycle [25], this possibility was tested next. Cells were exposed to COM $(400 \mu \mathrm{g} / \mathrm{mL})$ or PE $(50 \mu \mathrm{g} / \mathrm{mL})$ alone or their combination $(\mathrm{COM}+\mathrm{PE})$ for $6 \mathrm{~h}$ and subjected to cell cycle analysis. Compared to controls, the $\mathrm{G}_{1}$-phase cell population increased to $69.2 \%$ (i.e., about $41 \%$ increase) while the S-phase population decreased to $20.5 \%$ (about $47 \%$ decrease) with COM exposure (Fig. 5). This accumulation of cells in the $\mathrm{G}_{1}$ phase is known as a $\mathrm{G}_{1}$ cell cycle arrest [26], which would subsequently lead to the growth cessation and cell viability reduction. However, PE significantly decreased the $G_{1}$ cell population (increased by COM) to $59.1 \%$ and increased the $\mathrm{S}$ population (reduced by COM) to $30.3 \%$ (Fig. 5). These findings suggest that some of cells trapped in the $G_{1}$ phase were moving/entering to the $S$ phase, partially reversing a $G_{1}$ cell cycle arrest. Thus, COM may substantially induce a $\mathrm{G}_{1}$ arrest (by interrupting the $\mathrm{G}_{1}-\mathrm{S}$ cell cycle progression) but PE is capable of partially blocking it, allowing the cells to continue proliferating.

\section{Discussion}

Despite numerous studies on nephrolithiasis being currently underway, the pathogenesis of kidney stone has not been fully understood. Nowadays, oxidative stress is increasingly believed to play a significant role in nephrolithiasis $[8,9]$. $\mathrm{CaOx}$ or its crystal form known as COM has been shown to exert detrimental oxidative stress on renal cells, ultimately leading to kidney stone formation $[5,10]$. Exploring such a cytotoxic mechanism may give us a better understanding of nephrolithiasis. We also believe that it is crucial to find certain natural agents with the improved preventative effect on stone formation but with few side/adverse effects.

In this study, we examined if a bioactive mushroom extract, PE, might have antioxidant and renoprotective effects on renal tubular epithelial LLC-PK ${ }_{1}$ cells under oxidative stress mediated through $\mathrm{H}_{2} \mathrm{O}_{2}$ or COM. Both $\mathrm{H}_{2} \mathrm{O}_{2}$ and COM signifi- 


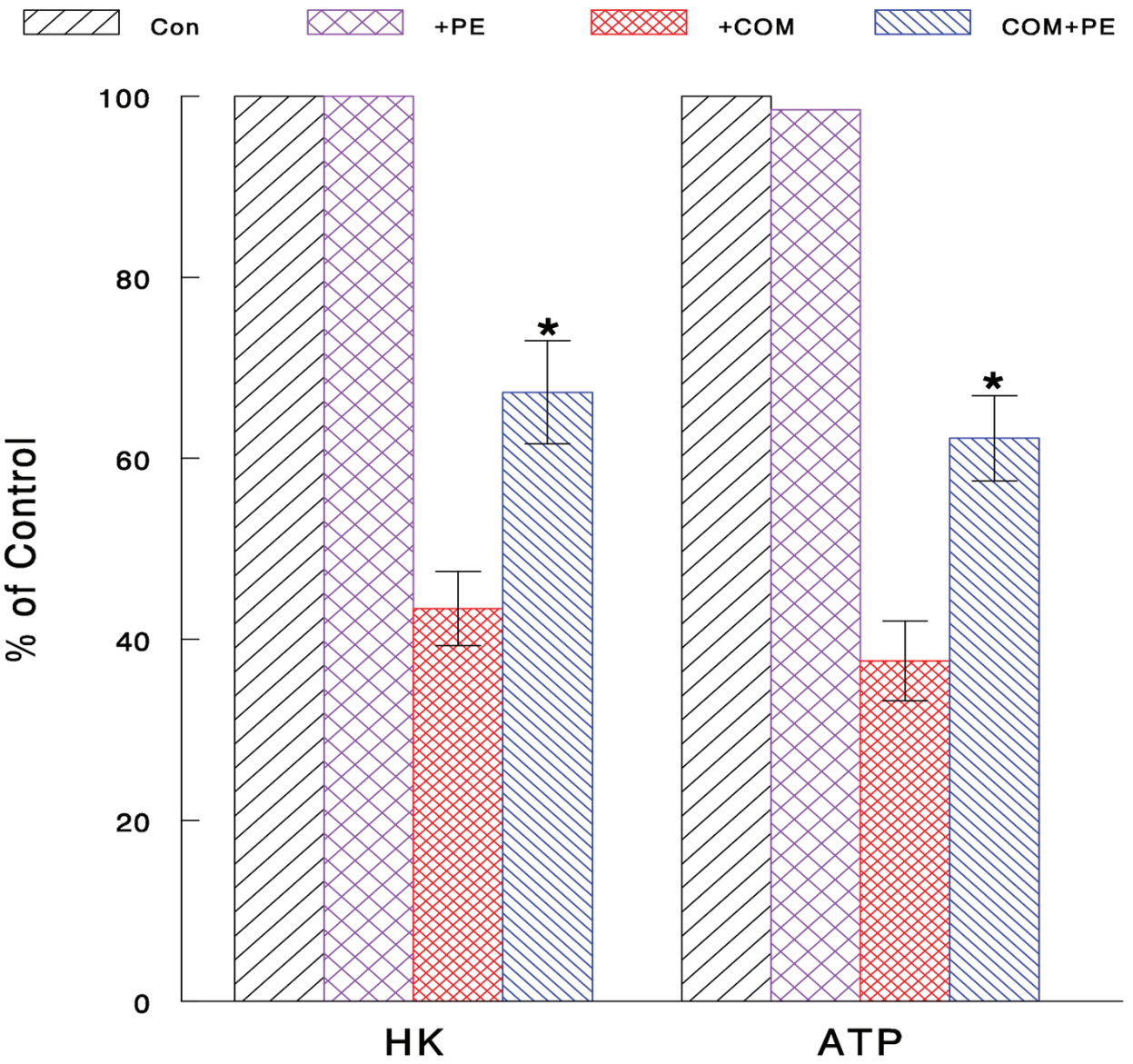

Figure 4. Inhibitory effect of COM on glycolysis and its prevention with PE. Cells exposed to COM $(400 \mu \mathrm{g} / \mathrm{mL}), \mathrm{PE}(50 \mu \mathrm{g} / \mathrm{mL})$, or PE combined with COM for $6 \mathrm{~h}$ were assayed for HK activity and cellular ATP level. All data are mean \pm SD from three separate experiments ( ${ }^{*} \mathrm{P}<0.05$ compared with COM-treated cells).

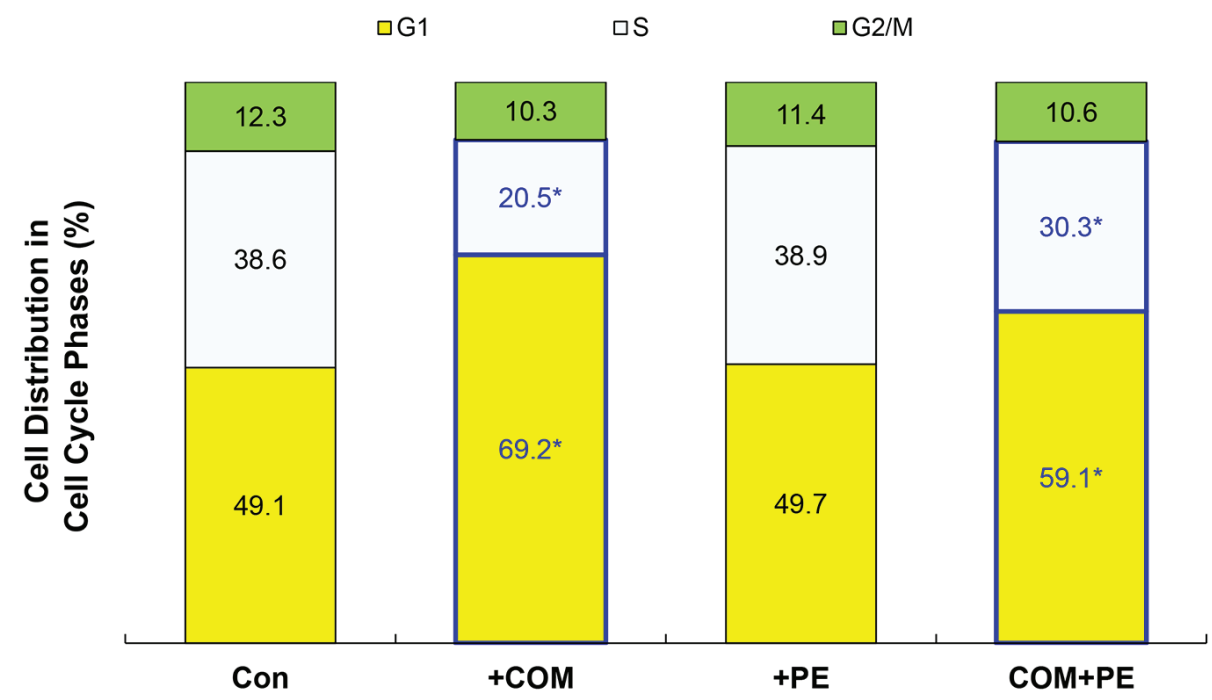

Figure 5. Cell cycle analysis. Cells exposed to COM $(400 \mu \mathrm{g} / \mathrm{mL})$, PE $(50 \mu \mathrm{g} / \mathrm{mL})$, or PE combined with COM for $6 \mathrm{~h}$ were subjected to cell cycle analysis. The data are representatives of three independent experiments $\left({ }^{*} \mathrm{P}<0.05\right.$ compared with controls). 
cantly reduced cell viability with the $\mathrm{IC}_{50}$ of $70 \mu \mathrm{M}$ and 400 $\mu \mathrm{g} / \mathrm{mL}$ for $\mathrm{H}_{2} \mathrm{O}_{2}$ and $\mathrm{COM}$, respectively. Such a cell viability reduction was also associated with severe oxidative stress exerted on cells (Fig. 2). However, PE was capable of significantly reducing the severity of such oxidative stress (Fig. 2) but increasing cell viability reduced by oxidative stress (Fig. 3). Therefore, PE may have antioxidant activity against oxidative stress, protecting renal cells from destructive oxidative attack.

We yet know little about how oxidative stress mediated through $\mathrm{H}_{2} \mathrm{O}_{2}$ or $\mathrm{COM}$ would lead to the cell viability reduction and how PE might prevent it. Nevertheless, it should be noted that our aim was to address if COM would exert oxidative stress, cause renal cell injury, and may eventually facilitate kidney stone formation. We then found that COM did exert oxidative stress (assessed by LPO assay) and induced renal cell injury evidenced by a significant reduction in cell viability. This finding is virtually comparable to what we found in $\mathrm{H}_{2} \mathrm{O}_{2}$. It should be reminded again that $\mathrm{H}_{2} \mathrm{O}_{2}$ was used as just a positive mediator of oxidative stress in this study.

We next explored how such a COM-induced cell viability reduction was carried out, focusing on glycolysis. It is a metabolic process where glucose goes through the glycolytic pathway and is eventually converted to ATP. This energy (ATP) metabolism is the key to cell proliferation and survival [23, 24]. There are several crucial parameters that can be used to assess the status of glycolysis, and two of such parameters, HK activity and ATP synthesis, were chosen for assessing how glycolysis would be affected by COM-mediated oxidative stress. HK is one of the key glycolytic enzymes involved in the first step in glycolysis, which is also the irreversible committed step [23]. A blocking or inhibition of this step will shut down the rest of the glycolytic pathway, resulting in no new ATP synthesis or critical ATP depletion. In fact, both HK activity and cellular ATP level were significantly reduced by COM (Fig. 4), indicating the inhibition of glycolysis. However, PE significantly increased the COM-reduced HK and ATP levels, implying that the glycolysis inhibition by COM was effectively reversed by PE. Thus, COM-mediated oxidative stress could inhibit glycolysis but PE may prevent such an inhibition to keep cells alive and growing.

In addition, we also examined possible effect of COMmediated oxidative stress on cell cycle and found a $\mathrm{G}_{1}$ cell cycle arrest having been induced by COM. However, PE partially reversed such a cell cycle blockage, allowing some of cells to move from the G1 to the $\mathrm{S}$ phase. Thus, although COM may target cell cycle, PE could yet block it to ensure cell proliferation.

Taken together, the glycolysis inhibition coupled with a cell cycle arrest induced by COM may account for the growth cessation and cell viability reduction in renal $\left(\mathrm{LLC}_{-} \mathrm{PK}_{1}\right)$ cells.

Overall, PE appears to significantly prevent adverse effects mediated through COM, especially protecting renal cells from oxidative attack. This may have significant implication in prevention of $\mathrm{CaOx}$ stone formation induced by oxidative stress. During the development of kidney stone, crystallization of $\mathrm{CaOx}$ (i.e., $\mathrm{COM}$ ) is the primary element required for stone formation, but these crystals would never develop into a stone without a "matrix", such as glycoproteins, glycosaminoglycans, or lipids [27]. For instance, as the brush border membrane of renal epithelial cells is rather susceptible to oxi- dative stress, its membranous debris (due to cell injury) could likely become such a potential matrix for crystal aggregation [10]. As shown in this study, COM could induce a cell viability reduction through cell injury (directly caused by oxidative stress) and also through the glycolysis inhibition and a cell cycle arrest, which would ultimately result in cell death. It is then plausible that such injured or dead cells could be involved in the COM-cell interaction $[9,10]$ and/or become a matrix [27], further promoting stone formation. Nevertheless, if oxidative stress (exerted by COM) were effectively diminished or reduced by certain antioxidants such as PE, that could significantly reduce the incidence of kidney stones, owing to prevention of COM formation as well as protection of renal epithelial cells from oxidative attack.

Although the data obtained from this in vitro study look promising and encouraging, more studies using animals (in vivo) are required for confirmation and such study is currently underway in our laboratory.

In conclusion, the present study shows that $\mathrm{PE}$ has antioxidant and renoprotective effects against severe oxidative stress exerted by $\mathrm{H}_{2} \mathrm{O}_{2}$ or COM. Such oxidative stress would inhibit glycolysis, deplete cellular ATP, and also interfere with the cell cycle progression (a $\mathrm{G}_{1}$ cell cycle arrest). These adverse effects may account for the resulting cell viability reduction but could be effectively prevented by PE. Therefore, PE is a promising agent with antioxidant activity, capable of protecting renal cells from oxidative assault, and may also reduce the incidence of $\mathrm{CaOx}$ stone cases. Further studies are warranted.

\section{Acknowledgments}

We thank Mike Shirota and Donna Noonan (Mushroom Wisdom, Inc.) for generously providing us with Poria mushroom extract and their courteous assistance in this study.

\section{Financial Disclosure}

No competing financial interests exist.

\section{References}

1. Baud L, Ardaillou R. Reactive oxygen species: production and role in the kidney. Am J Physiol. 1986;251(5 Pt 2):F765-776.

2. Baliga R, Ueda N, Walker PD, Shah SV. Oxidant mechanisms in toxic acute renal failure. Am J Kidney Dis. 1997;29(3):465-477.

3. Diamond JR. The role of reactive oxygen species in animal models of glomerular disease. Am J Kidney Dis. 1992;19(3):292-300.

4. Andreoli SP, McAteer JA. Reactive oxygen moleculemediated injury in endothelial and renal tubular epithelial cells in vitro. Kidney Int. 1990;38(5):785-794.

5. Thamilselvan S, Hackett RL, Khan SR. Lipid peroxidation in ethylene glycol induced hyperoxaluria and cal- 
cium oxalate nephrolithiasis. J Urol. 1997;157(3):10591063.

6. Scheid C, Koul H, Hill WA, Luber-Narod J, Kennington L, Honeyman T, Jonassen J, et al. Oxalate toxicity in LLC-PK1 cells: role of free radicals. Kidney Int. 1996;49(2):413-419.

7. Hesse A, Siener R. Current aspects of epidemiology and nutrition in urinary stone disease. World J Urol. 1997;15(3):165-171.

8. Bigelow MW, Wiessner JH, Kleinman JG, Mandel NS. Calcium oxalate crystal attachment to cultured kidney epithelial cell lines. J Urol. 1998;160(4):1528-1532.

9. Wiessner JH, Hasegawa AT, Hung LY, Mandel GS, Mandel NS. Mechanisms of calcium oxalate crystal attachment to injured renal collecting duct cells. Kidney Int. 2001;59(2):637-644.

10. Thamilselvan S, Khan SR, Menon M. Oxalate and calcium oxalate mediated free radical toxicity in renal epithelial cells: effect of antioxidants. Urol Res. 2003;31(1):39.

11. Selvam R. Calcium oxalate stone disease: role of lipid peroxidation and antioxidants. Urol Res. 2002;30(1):3547.

12. Fishman AI, Green D, Lynch A, Choudhury M, Eshghi M, Konno S. Preventive effect of specific antioxidant on oxidative renal cell injury associated with renal crystal formation. Urology. 2013;82(2):489 e481-487.

13. Rios JL. Chemical constituents and pharmacological properties of Poria cocos. Planta Med. 2011;77(7):681691.

14. Wang Y, Zhang M, Ruan D, Shashkov AS, Kilcoyne M, Savage AV, Zhang L. Chemical components and molecular mass of six polysaccharides isolated from the sclerotium of Poria cocos. Carbohydr Res. 2004;339(2):327334.

15. Zhao YY, Lei P, Chen DQ, Feng YL, Bai X. Renal metabolic profiling of early renal injury and renoprotective effects of Poria cocos epidermis using UPLC Q-TOF/ HSMS/MSE. J Pharm Biomed Anal. 2013;81-82:202209.

16. Chen X, Zhang L, Cheung PC. Immunopotentiation and anti-tumor activity of carboxymethylated-sulfated be- ta-(1-->3)-d-glucan from Poria cocos. Int Immunopharmacol. 2010;10(4):398-405.

17. Zhang L, Ravipati AS, Koyyalamudi SR, Jeong SC, Reddy N, Bartlett J, Smith PT, et al. Anti-fungal and antibacterial activities of ethanol extracts of selected traditional Chinese medicinal herbs. Asian Pac J Trop Med. 2013;6(9):673-681.

18. Zhou L, Zhang Y, Gapter LA, Ling H, Agarwal R, Ng KY. Cytotoxic and anti-oxidant activities of lanostanetype triterpenes isolated from Poria cocos. Chem Pharm Bull (Tokyo). 2008;56(10):1459-1462.

19. Li TH, Hou CC, Chang CL, Yang WC. Anti-Hyperglycemic Properties of Crude Extract and Triterpenes from Poria cocos. Evid Based Complement Alternat Med. 2011;2011.

20. Fuchs SM, Heinemann C, Schliemann-Willers S, Hartl H, Fluhr JW, Elsner P. Assessment of anti-inflammatory activity of Poria cocos in sodium lauryl sulphateinduced irritant contact dermatitis. Skin Res Technol. 2006;12(4):223-227.

21. Feng YL, Lei P, Tian T, Yin L, Chen DQ, Chen H, Mei Q, et al. Diuretic activity of some fractions of the epidermis of Poria cocos. J Ethnopharmacol. 2013;150(3):11141118 .

22. Dargel R. Lipid peroxidation - a common pathogenetic mechanism? Exp Toxicol Pathol. 1992;44(4):169-181.

23. Pelicano $\mathrm{H}$, Martin DS, Xu RH, Huang P. Glycolysis inhibition for anticancer treatment. Oncogene. 2006;25(34):4633-4646.

24. Simons AL, Mattson DM, Dornfeld K, Spitz DR. Glucose deprivation-induced metabolic oxidative stress and cancer therapy. J Cancer Res Ther. 2009;5(Suppl 1):S2-6.

25. Loar P, Wahl H, Kshirsagar M, Gossner G, Griffith K, Liu JR. Inhibition of glycolysis enhances cisplatin-induced apoptosis in ovarian cancer cells. Am J Obstet Gynecol. 2010;202(4):371 e371-378.

26. Sherr CJ. The Pezcoller lecture: cancer cell cycles revisited. Cancer Res. 2000;60(14):3689-3695.

27. Khan SR, Glenton PA, Backov R, Talham DR. Presence of lipids in urine, crystals and stones: implications for the formation of kidney stones. Kidney Int. 2002;62(6):20622072. 